\title{
PENELUSURAN KAWASAN ALUN-ALUN BUNDER KOTA MALANG SEBAGAI OPEN SPACE RANCANGAN IR KARSTEN
}

\author{
R. Dimas Widya Putra \\ Independent Urban Researcher, Alumni Institut Teknologi Sepuluh Nopember, Surabaya \\ r.dimasp@yahoo.com
}

\begin{abstract}
Abstrak
Kawasan Alun-Alun Bunder memiliki peranan yang sangat penting terhadap perkembangan Kota Malang pada masa kependudukan Belanda. Kawasan Alun-Alun Bunder merupakan kebijakan perluasan pembangunan kota ke II (Bouwplan II) yang memiliki luas sebesar $15.547 \mathrm{M}^{2}$, alasan perancangan Alun-Alun Bundar adalah untuk membentuk pusat pemerintahan yang baru, inilah yang mendasari pihak Kotamadya (Gemeente) membuat rencana perluasan kota ke II (Bouwplan II). Daerah ini dinamakan sebagai Gouverneur-Generaalbuurt. Rencana tersebut baru direalisasikan pada tahun 1922. Daerah ini kemudian terkenal dengan sebutan Alun-Alun Bunder. Tujuan studi ini adalah untuk mengetahui pola perkembangan Kawasan Alun-Alun Bunder, identifikasi fungsi landscape Kawasan Alun-Alun Bunder sebagai landmark Kota Malang dengan tujuan sebagai ruang interaksi masyarakat. Teknik analisis yang digunakan, yaitu teknik analisis diachronic, analisis deskriptif - evaluatif terhadap penelusuran pola linkage dan teknik analisis synchronic. Hasil studi diketahui bahwa Alun-Alun Bunder merupakan bentuk design ideal alunalun yang diinginkan oleh pemerintahan Belanda pada masa itu. Bahwa infrastruktur berupa permukiman, pendidikan dan sarana transportasi direncanakan mengikuti peran dari Alun-Alun Bunder sebagai pusat pemerintahan Belanda. Strategi menguatkan nilai sejarah pada Kawasan Alun-Alun Bunder diperoleh melalui penguatan linkage terhadap objek historis yang terdapat di dalamnya.
\end{abstract}

Kata kunci: Alun-Alun Bunder, landmark, perancangan kota, ruang terbuka kota

\begin{abstract}
Title: Searching of Alun-Alun Bunder District in Malang City as Open Space which was Built by Ir Karsten

Alun-Alun Bunder plays an important role for city of Malang development during Dutch collonialism. Alun-Alun Bunder was the policy for expanding the second city (Bouwplan II) which had the total size of $15.547 \mathrm{M}^{2}$. the reason of Alun-Alun Bunder designing was to establish the new administration pivot, this main reason became the basis for the governance at that time (Gemeente) to design the second city expansion (Bouwplan II). This district was named as Gouverneur-Generaalbuurt. The design was realized in 1922. In subsequent, this area was known as 'Alun-Alun Bunder'. The research purpose are to know the development pattern of Alun-Alun Bunder, identification of landscape function as the landmark which use as interaction space. Analysis technique which is used in this research, consist of ; diachronic reading, descriptiveevaluation related by linkage pattern and synchronic reading. The result shown that Alun-Alun Bunder is the best city hall model which was desired by Dutch government. The infrastructure, among them are; settlement, education and transportation are designed to follow the role of AlunAlun Bunder as the core of Dutch administration. The strategy to strengthen the historical value in Alun-Alun Bunder is gained by strengthening the linkage towards historic object which exist inside.
\end{abstract}

Keywords: Alun-Alun Bunder, landmark, urban design, urban open space 


\section{Pendahuluan}

Kota Malang merupakan kota yang memiliki pengaruh kuat terhadap budaya, gaya hidup dan bentuk tata kota yang dibawa oleh masyarakat Belanda, terdapat beberapa warisan peninggalan arsitektural dan bangunan Belanda di Kota Malang, antara lain: Ijen Boulevard, Toko Oen, Splendid Inn, Wisma Tumapel dan Balai Kota Malang Raya. Salah satu kawasan potensial yang berada di Kota Malang untuk dikembangkan sebagai tujuan pariwisata di dalam kota adalah kawasan Alun-Alun Bunder. Menurut Handinoto, (1996) Alun-Alun Bunder memiliki nilai historis dan karakteristik open space yang dirancang menyerupai bentuk desain model umum perkotaan di Eropa. Adapun nilai sejarah pada Kawasan Alun-Alun Bunder dapat dilihat dari keberadaan bangunan Kolonial yang berkembang mengikuti perkembangan perencanaan Alun Alun Bunder sebagai karya arsitek dan perencana kota, yaitu Ir Karsten, dampaknya Kawasan Alun-Alun Bunder menjadi landmark kawasan tehadap objek di sekitarnya. Berdasarkan peruntukannya merupakan kawasan pemerintahan, cagar budaya dan pariwisata (RTRW Kota Malang 2010 -2030). Berdasarkan fenomena ini maka diangkat Alun-Alun Bunder sebagai sebuah objek studi.

Studi ini diangkat karena potensi sejarah yang terdapat di Kawasan Alun-Alun Bunder Kota Malang dan didasari untuk membuktikan kebenaran studi terdahulu berkenaan dengan Alun- Alun Bunder sebagai pusat pemerintahan penganti Alun-Alun Merdeka yang dianggap kuno karena pengaruh Jawa yang kuat dan masyarakat Belanda kurang menyukai bentuk tesebut, Studi ini merupakan pembuktian lanjutan terhadap studi terdahulu mengenai Alun-Alun Bunder yang dibuktikan kebenarannya hingga saat ini dengan teknik analisis yang relevan. Rumusan masalah dalam studi ini adalah sebagai berikut: kurangnya studi tipologi Kawasan Alun-Alun Bunder mengantikan peran Alun -Alun Merdeka serta belum ada pembuktian dua dimensi tipologi Kawasan AlunAlun Bunder semenjak masih berupa tanah lapang hingga tahun 2015 ahkir.

Menanggapi fenomena, potensi dan permasalahan di lapangan maka diangkat tujuan studi, antara lain: untuk mengetahui kebenaran tipologi perkembangan, perubahan Kawasan Alun-Alun Bunder terhadap fungsi Alun-Alun Merdeka, serta mengidentifikasi perubahan tipologi dua dimensi Kawasan Alun-Alun Bunder dan perubahan landscape taman mulai dari belum terbangun hingga saat ini.

\section{Metode Penelitian}

Pendekatan yang digunakan adalah tipologi, historis dan topografi, ketiganya saling berkaitan antara satu dengan yang lainnya. Pendekatan tipologi dipakai untuk mengklasifikasikan suatu objek studi (bangunan dan lingkungan) ke dalam tipe tertentu, baik langgam, geometri/bentuk, maupun fungsinya. Pendekatan historis untuk menelusuri asal-usul dan perkembangan objek studi (bangunan dan lingkungan) baik yang terkait dengan sejarah perkembangan arsitektur kota maupun perjuangan bangsa. Pendekatan topografi untuk menjelaskan letak dan tatanan/struktur formal suatu tempat, baik dalam skala Kota Malang maupun Kawasan Alun-Alun Bunder (Rossi,1982). Sebagai lanjutan dari gabungan teknik analisis tipologi- 
morfologi di atas, maka dirujuk teknik analisis synchronic reading dan analisis diachronic reading. Analisis synchronic reading, yaitu membaca atau melakukan intrepetasi secara sinkron, menyelaraskan berbagai informasi yang didapatkan pada saat yang sama. Analisis diachronic reading adalah penelusuran asal usul sejarah yang berkaitan dengan objek Kawasan Alun-Alun Bunder yang distudi (Darjosanjoto, 2006). Metode pengumpulan data studi ini menggunakan beberapa tahapan, antara lain :

1. Dokumentasi: berupa gambaran dan suasana Kawasan Alun-Alun Bunder, rangkaian massa bangunan;

2. Interview: dengan menggunakan interview bebas terpimpin, yaitu dalam melakukan wawancara peneliti dengan pedoman pertanyaan, teknik yang digunakan, yaitu wawancara dengan budayawan dan pakar mengenai kesejarahan Kawasan Alun-Alun Bunder;

3. Observasi: kondisi situasi Kawasan Alun-Alun Bunder, kondisi Infrastruktur, kondisi bangunan lama dan baru; dan

4. eksplorasi literatur.

Metode penyajian data studi ini disajikan dalam beberapa tahapan, antara lain:

1. penyajian data dalam bentuk peta/gambar, termasuk

lokasi penelitian.

2. penyajian data bangunan pada Kawasan Alun-Alun Bunder dalam bentuk diagram / skesta gambar.

3. penyajian data khusus, yang merupakan gabungan informasi yang saling berkaitan yang dapat diwujudkan dalam bentuk perpaduan antara tampilan gambar dan hasil pengukuran atau perhitungan unsur-unsur yang ditampilkan dalam gambar.

Teknik analisis yang digunakan dalam studi ini dengan menggunakan analisis secara desktiptif kualitatif mengacu pada teori-teori tentang tipologi morfologi dengan pendekatan studi sebagai berikut:

1. fokus pada struktur jalinan ruang kota dan pola pertumbuhan dan perubahan yang terjadi.

2. mempertimbangkan hunian sebagai dasar tipe jalinan ruang kota.

3. mencermati bahwa pertumbuhan dimulai dari bangunan-bangunan. pertama tempat hunian yang ada merefleksi tuntutan sosial, ekonomi, dan budaya pada masa terkait.

4. keragaman yang stimulant menjadikan tipe menjadi besar dan lebih khusus / mengecil dan menjadi lebih sederhana.

Sesuai dengan tujuan dan sasaran yang telah diharapkan, maka terkait dengan perancangan kota yang diwujudkan dalam penelusuran Kawasan AlunAlun Bunder, maka analisis yang dipergunakan mencakup:

1. analisis diachronic reading;

2. analisis deskriptif evaluatif; dan

3. analisis syncronic reading.

Analisis linkage yang digunakan untuk menunjang teknik analisis syncronic reading kawasan studi dengan memetakan pola sirkulasi path, nodes serta infrastruktur yang terdapat pada wilayah studi. Dari serangkaian analisis tersebut, maka akan dihasilkan pola linkage kawasan. Studi ini menggunakan pendekatan urban open space, konservasi dan elemenperancangan kota. dalam menentukan objek landscape Alun-Alun Bunder dan objek bangunan kuno di sekitar yang hendak dikaji, Menurut Moughtin (1992), sebuah kota pada dasarnya 
memerlukan suatu ruang terbuka kota atau square, yang mampu menunjukan vitalitas kotanya. Ruang terbuka tersebut dibutuhkan untuk mengekspresikan banyak kegiatan masyarakat kota, baik secara fisik berupa visualisasi bangunannya maupun kegiatan di dalam square tersebut.

Trancik (1986) juga menyebutkan bahwa ruang terbuka publik di pusat kota merupakan urban void yang mewujudkan lambang dan wadah berkumpulnya suatu komunitas dalam masyarakat serta merepresentasi ikatan antara individu dengan lingkungan. Krier (1979) menyebutkan tipologi bentuk elemen ruang kota dalam hal ini urban space yang telah diklasifikasikan dalam beberapa tipologi umum seperti square, lingkaran dan segitiga dapat dijadikan sebagai referensi dalam mengamati dan mendeskripsikan koridor sub-urban. Hal ini dapat diamati melalui pengaruh potongan dan tampak bangunan pada ruang kota. Salah satu tipologi yang disarankan Krier dalam mendeskripsikan koridor sub-urban di antaranya adalah tipologi urban space berbentuk square.

Sebagai civic space, ruang terbuka publik memiliki arti suatu ruang luar yang terjadi dengan membatasi alam dan komponen-komponennya menggunakan elemen keras seperti pedestrian way, jalan, plasa, pagar beton dan sebagainya. Fungsi utama ruang publik sebagai aktivitas publik dapat dikatakan berhasil dengan memiliki kualitas untuk memenuhi apa yang diinginkan penggunanya. Carr (1992) menyebut terdapat tiga kualitas utama sebuah ruang publik, yaitu

1. tanggap (responsive), berarti bahwa ruang tersebut dirancang dan dikelola dengan mempertimbangkan kepentingan para penggunanya.
2. demokratis (democratic), berarti bahwa hak para pengguna ruang publik tersebut terlindungi, pengguna ruang publik bebas berekspresi dalam ruang tersebut, namun tetap memiliki batasan tertentu.

3. bermakna (meaningful), berarti mencakup adanya ikatan emosional antara ruang tersebut dengan kehidupan para penggunanya.

Sebagai ruang publik, Alun-Alun Bunder memiliki ketiga kualitas seperti yang diutarakan oleh Carr (1992), bahwa Alun - Alun Bunder dirancang oleh Ir. Herman Karsten untuk memenuhi kebutuhan masyarakat akan ketiga hal tersebut. Dikaitkan dengan teori konservasi, maka konservasi Kawasan Alun-Alun Bunder memiliki tujuan untuk melestarikan objek bersejarah yang terdapat di dalam Kawasan Alun-Alun Bunder dengan memunculkan landscape Alun Alun Bunder sebagai landmark. Dalam menelusuri karakter pembentukan kawasan, maka konsep dari teori Spreiregen (1985) digunakan untuk membantu analisis karakter dan pembentuk kawasan studi di Kawasan Alun-Alun Bunder yang di dalamnya berkaitan dengan pembentukan dan pengembangan kawasan, dalam bentuk pemetaan kawasan, pemetaan pola sarana dan prasarana, bentuk lay out grid, pola jaringan jalan dan blok massa bangunan.

Makna sebuah tempat diperoleh dari tinjauan teori perancangan kota, yaitu teori linkage dan teori place (Trancik, 1986). Teori linkage digunakan untuk mengetahui posisi objek public space pada Kawasan Alun-Alun Bunder dengan objek penting di sekitarnya, dalam penelitian ini untuk teori citra kota (Kevin Lynch, 1969) hanya 
menggunakan elemen yang sesuai, antara lain:

- landmark;

- path; dan

- nodes.

Untuk membentuk konsep landscape sebagai indentitas dari objek di sekitar kawasan, maka dalam studi ini memperhatikan elemen perancangan kota dari Shirvani (1985) yang dapat digunakan sebagai pokok bahasan analisis, berdasarkan klasifikasi untuk pokok bahasan yang sesuai digunakan dalam penelitian ini, yaitu

- tata guna lahan; dan

- sirkulasi.

Dari serangkaian hasil sintesa kajian teori di atas menghasilkan strategi analisis untuk mengkaji kebenaran tipologi.

\section{Hasil dan Pembahasan}

Krier (1979) menyebutkan tipologi bentuk elemen ruang kota dalam hal ini urban space yang telah diklasifikasikan dalam beberapa tipologi umum seperti square, lingkaran dan segitiga dapat dijadikan sebagai referensi dalam mengamati dan mendeskripsikan koridor sub-urban, dianalisis bahwa Alun-Alun Bunder merupakan open space dengan bentuk lingkaran yang di sekitarnya dikelilingi oleh bangunan bersejarah, adapun yang termasuk bagian dari Kawasan Alun-Alun Bunder, yaitu Kawasan Splendid, Sungai Brantas, komplek SMA Tugu Malang, Balai Kota dan Hotel Tugu. Kawasan Alun-Alun Bunder ini terletak di kelurahan Kelurahan Kidul Dalem, kawasan studi memiliki batas administrasi antara lain sebagai berikut (Gambar 1):

Batas utara : Jalan Suropati

Batas timur : Jalan Kartanegara
Batas selatan : Jalan Majopahit

Batas barat : Jalan Majopahit

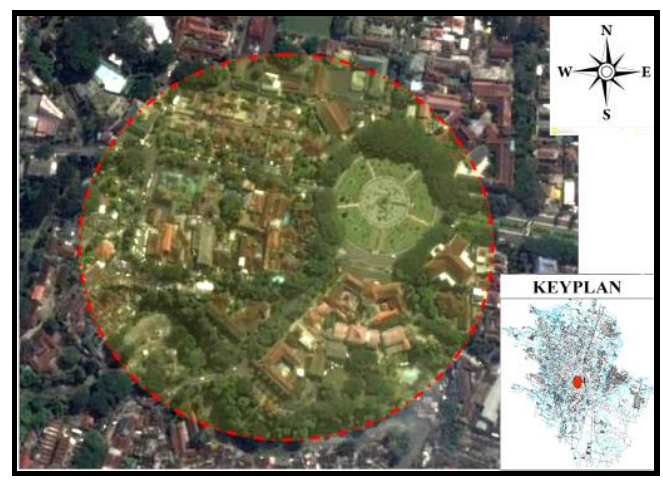

Gambar 1. Batasan wilayah studi

Sumber: Google earth (2016)

Dokumentasi perubahan yang bersifat kesejarahan pada Kawasan Alun-Alun Bunder ditampilkan dalam Gambar 2.

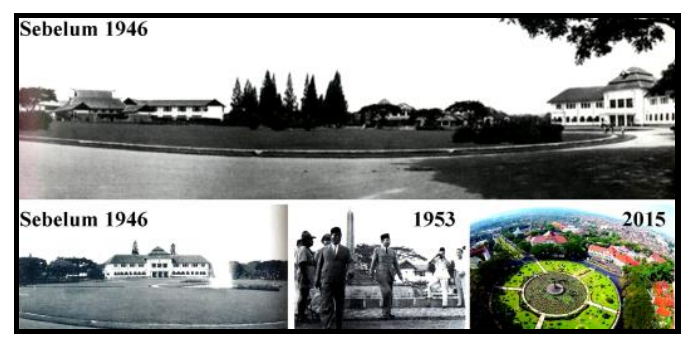

\section{Gambar 2. Foto Alun-Alun Bunder}

Sumber: Dokumentasi museum malang tempo doloe dan balorwilmalang.jatimprov.go.id (2016)

Bentuk tipologi Alun - Alun Bunder dikelilingi oleh fasilitas berupa bangunan bersejarah dan bentang alam Sungai Brantas yang merupakan point of view dari Kawasan Alun-Alun Bunder. (Gambar 3)

Pembagian objek bangunan kolonial / sejarah peninggalan Belanda merujuk pada peta pola ruang di atas adalah sebagai berikut ini (Gambar 4)

Ditunjukkan oleh nomor satu (lihat Gambar 3 peta guna lahan kawasan penelitian) merupakan Balai Kota Malang yang terletak di depan AlunAlun Bunder, bangunan ini merupakan 
bangunan cagar budaya di Kota Malang (Gambar 5).

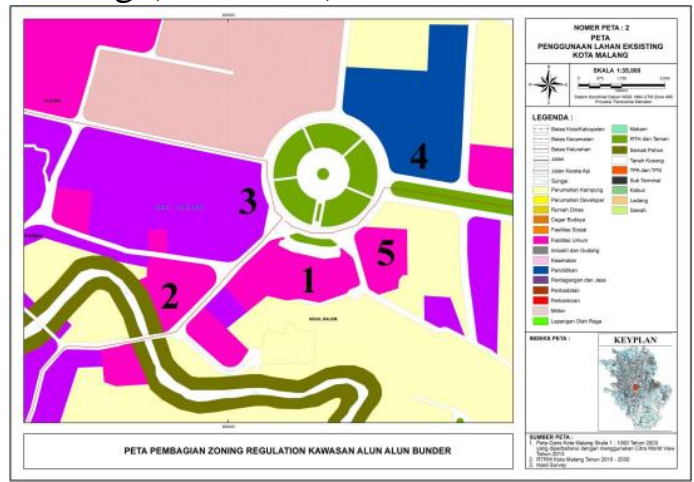

Gambar 3. Pembagian guna lahan Sumber: Diolah dari Masterplan Kota Malang 2010-2030

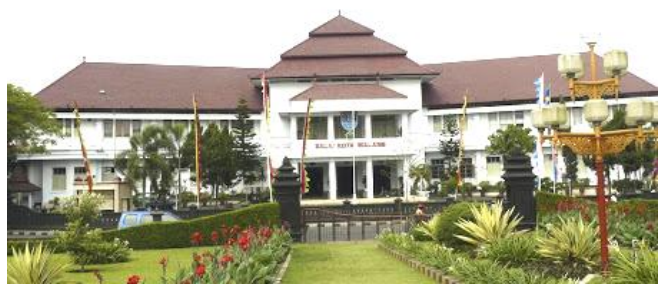

Gambar 4. Balai Kota Malang

Sumber: www.panoramio.com (2016)

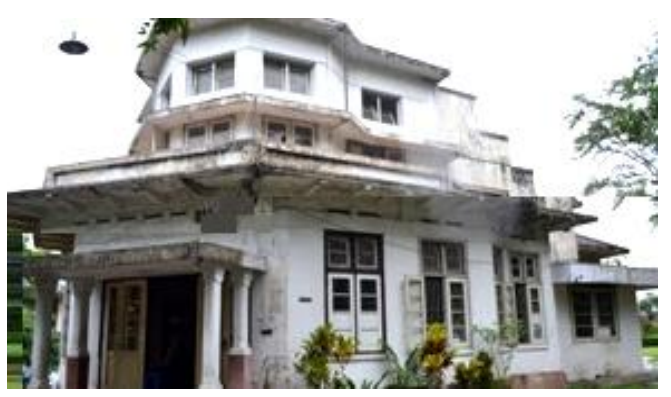

Gambar 5. Wisma Tumapel Malang

Sumber: malangonline.com (2016)

Ditunjukkan oleh nomor dua (Gambar 3) merupakan Wisma Tumapel, bangunan ini merupakan bangunan kolonial Belanda yang memiliki bentuk fasade yang masih asli seperti halnya permulaan dibangun, hanya terdapat renovasi perubahan pada atap bangunan. (Gambar 6)

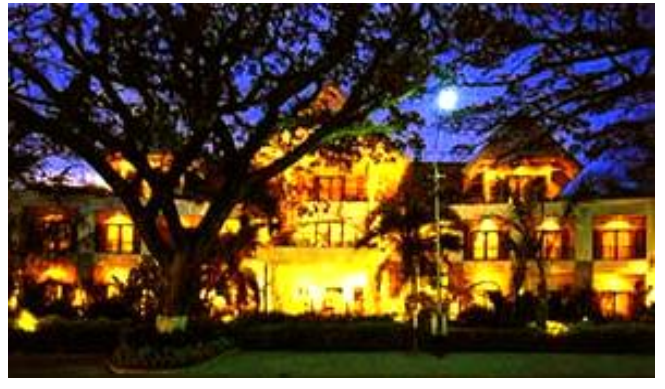

Gambar 6. Hotel Tugu

Sumber: halomalang.com (2016)

Ditunjukkan oleh nomor tiga (lihat Gambar 3) merupakan Hotel Tugu Malang yang berlokasi di depan AlunAlun Bunder pada bagian barat, Hotel Tugu merupakan bangunan peninggalan Belanda yang dengan bentuk fasade bangunan asli peninggalan Belanda. (Gambar 7)

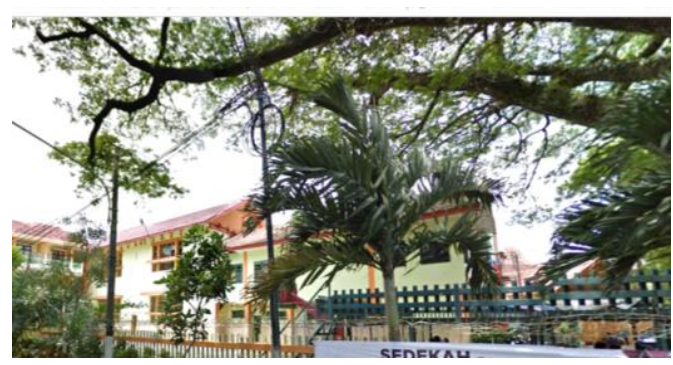

\section{Gambar 7. SMU Tugu}

Sumber: Doukumentasi Putra (2015)

Ditunjukkan oleh nomor empat (lihat gambar 3) merupakan SMU Tugu Malang yang terletak di depan AlunAlun Bunder pada bagian utara, bangunan SMU Tugu merupakan bangunan peninggalan Belanda dengan bentuk fasade asli peninggalan Belanda. (Gambar 8)

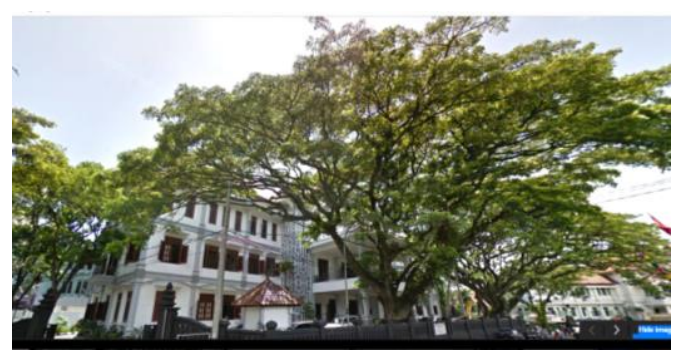

Gambar 8. Gedung DPRD

Sumber: Dokumentasi Putra (2015) 
Ditunjukkan oleh nomor lima (lihat Gambar 3), bangunan ini merupakan peninggalan Belanda dan telah direvitalisasi tanpa merubah bentuk asli bangunannya. Untuk mengetahui perkembangan Alun - Alun Bunder digunakan teknik analisis diachronic reading, yaitu dengan membaca perkembangan tipologi bangunan dan objek, dalam membantu analisis karakter dan pembentuk kawasan studi di Kawasan Alun-Alun Bunder yang di dalamnya berkaitan dengan pembentukan dan pengembangan guna lahan yang disajikan dalam bentuk pemetaan dua dimensi kawasan, pemetaan pola sarana dan prasarana, bentuk lay out grid, pola jaringan jalan dan blok massa bangunan. Disajikan dalam analisis pembacaan peta dua dimensi, yaitu (Gambar 9):

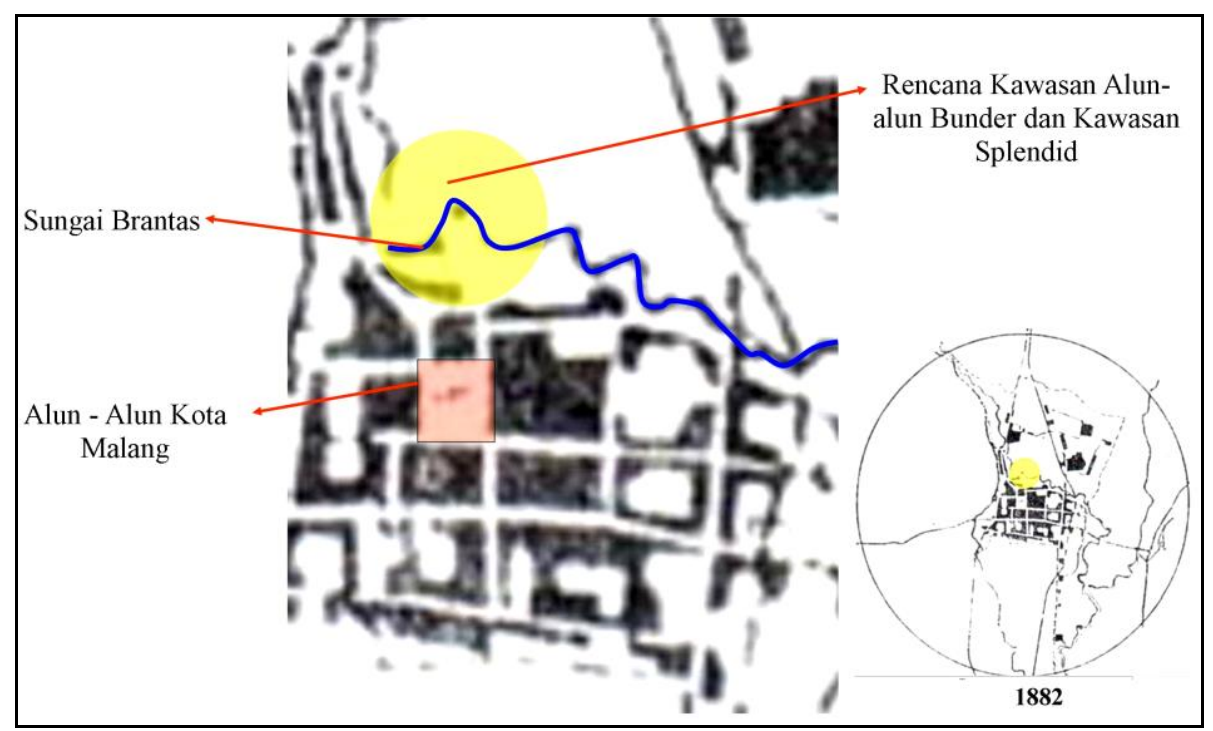

Gambar 9. Diachronic reading Alun-Alun Bunder tahun 1882

Sumber: Analisis yang diolah dari peta kuno Kota Malang dari buku Handinoto (1996)

Pada periode tahun 1882 merupakan awal mula pertumbuhan Kota Malang, dari pembacaan peta analisis solid dan void kawasan dapat di analisis bahwa pusat kotanya berada pada Kawasan Alun-Alun Kota Lama atau disebut dengan Alun-Alun Merdeka sebagai awal mula pertumbuhan infrastruktur di Kota Malang, Alun-Alun dengan model kotak mencirikan bahwa sebelum Belanda merencanakan Kota Malang, bentuk perancangan Kota Malang terpengaruh unsur kuat dari tipologi kota kuno di Jawa. Pada tahun 1882 dari analisis diachronic reading, Kawasan Alun-Alun Bunder belum direncanakan sebagai pusat pemerintahan Belanda. Pada Kawasan
Alun-Alun Bunder hanya dilalui oleh guna lahan berupa Sungai Brantas, dijelaskan bahwa solid (massa bangunan) yang dibaca dalam bentuk massa bangunan dengan legenda bewarna hitam belum terdapat di Kawasan Alun-Alun Bunder. (Gambar 10)

Pada tahun 1914 di Kota Malang terdapat periode perencanaan yang disebut Bouwplan I (notasi warna hijau), dimana direncanakan pada kawasan yang terletak di sebelah utara dari Alun-Alun Bunder, sama dengan periode 1882, tata guna lahan di sekitar landscape Alun-Alun Bunder belum direncanakan dan berkembang, karena pada tahun 1914 pemerintah Belanda 
belum memulai pengembangan Sungai Brantas dan masih belum Kawasan Alun-Alun Bunder sebagai pusat pemerintahan Kota Malang yang baru, Kawasan Alun-Alun Bunder terdapat sarana dan prasarana berupa bangunan dan jalan sebagai aksesnya. masih berupa gugusan bentang alam

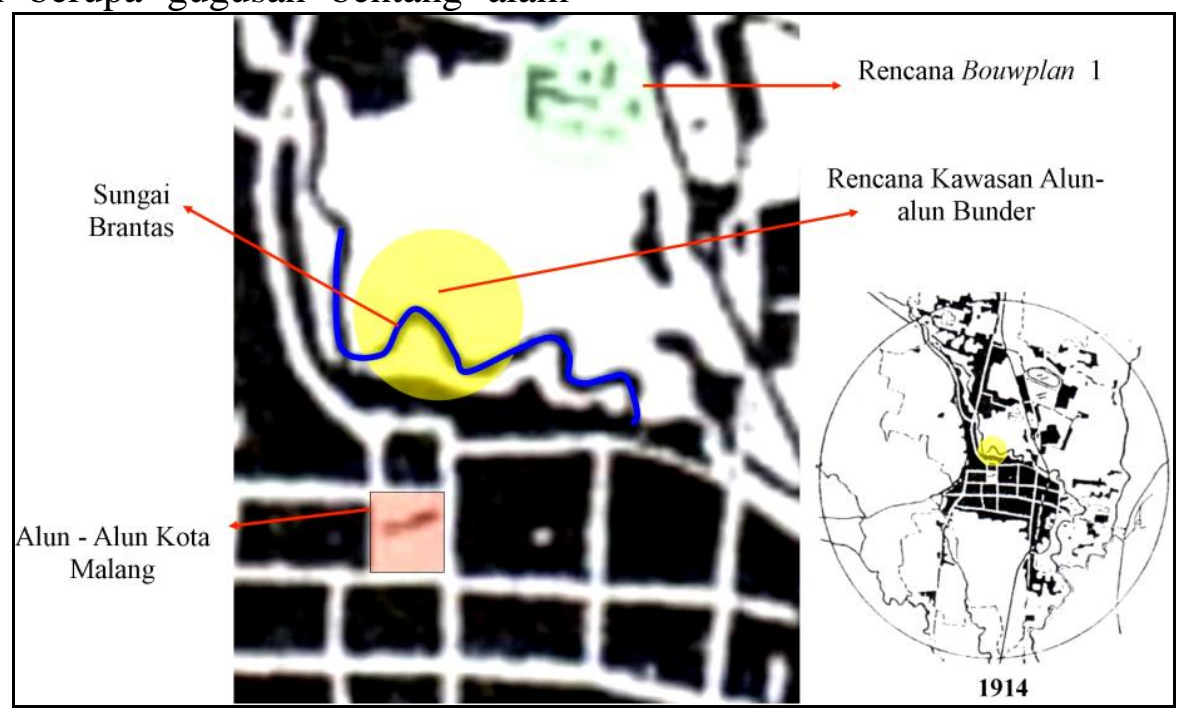

Gambar 10. Diachronic reading Alun-Alun Bunder tahun 1914

Sumber: Analisis yang diolah dari peta kuno Kota Malang dari buku Handinoto (1996)

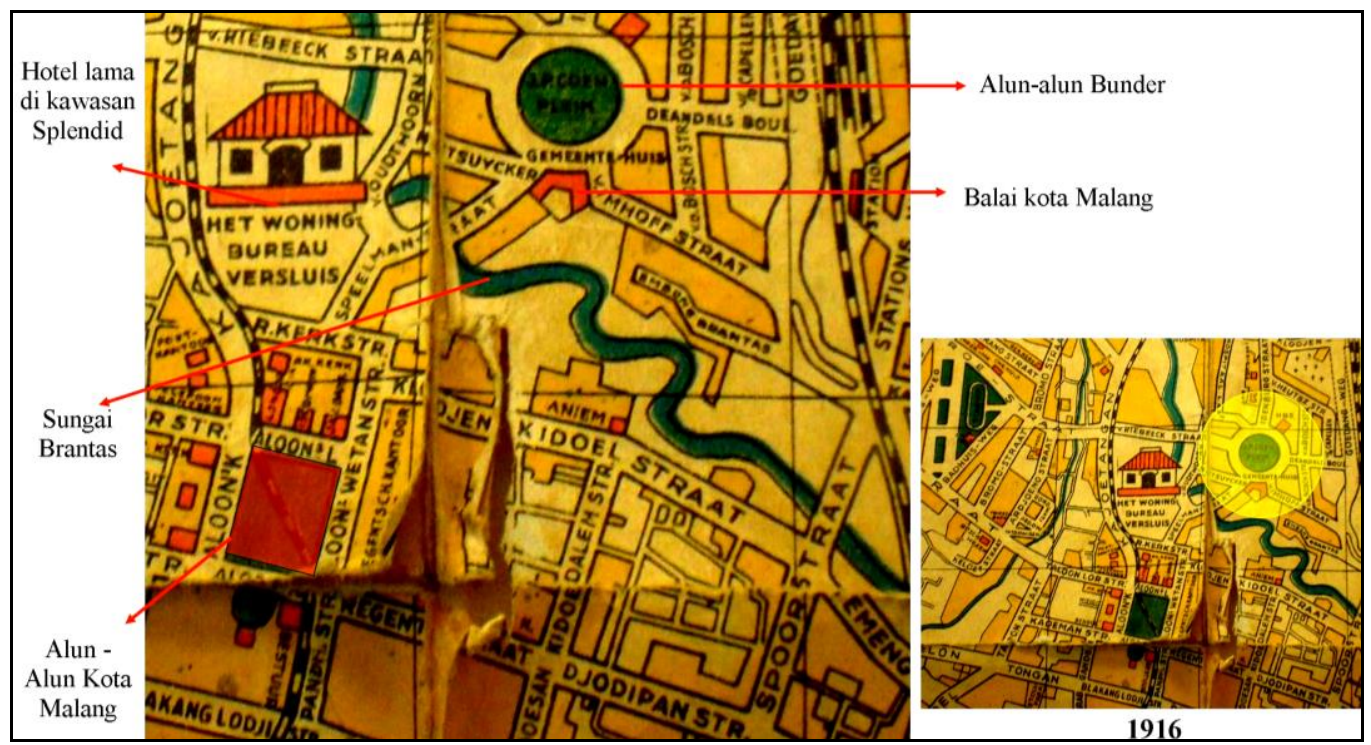

Gambar 11. Diachronic reading Alun-Alun Bunder tahun 1916

Sumber: Analisis yang diolah dari peta kuno Malang, galeri Museum Malang Tempo Doloe (2015)

Pada periode tahun 1916 Kawasan Alun-Alun Bunder sudah dalam tahap penentuan dan realisasi design dan visual, di samping itu perkembangan infrastruktur kawasan sudah mulai berkembang antara lain: jalan, jembatan dan ruang terbuka Alun-Alun Bunder, akan tetapi pada Kawasan Alun-Alun Bunder masih belum di ikuti oleh pertumbuhan pengunaan lahan yang massive berupa bangunan, antara lain: pasar, administrasi 
pemerintahan, Hotel dan permukiman warga Belanda.

Di tahun ini merupakan masa transisi tempat orang-orang Belanda banyak datang dan bertempat tinggal di Kota Malang, dibuktikan pada kawasan Alun-Alun Bunder terutama Kawasan Splendid terdapat Hotel sebagai tempat persinggahan bagi masyarakat Belanda yang bekerja di Surabaya. (Gambar 12)
Tahun 1920-an di Kawasan Alun-Alun Bunder mulai terdapat permukiman masyarakat Belanda karena pada masa ini perluasan kebijakan Bouwplan II sudah diterapkan oleh pemerintah Belanda melalui Ir Herman Karsten. Kawasan Alun-Alun Bunder mulai tumbuh infrastruktur (sarana dan prasarana) bangunan. (Gambar 13)

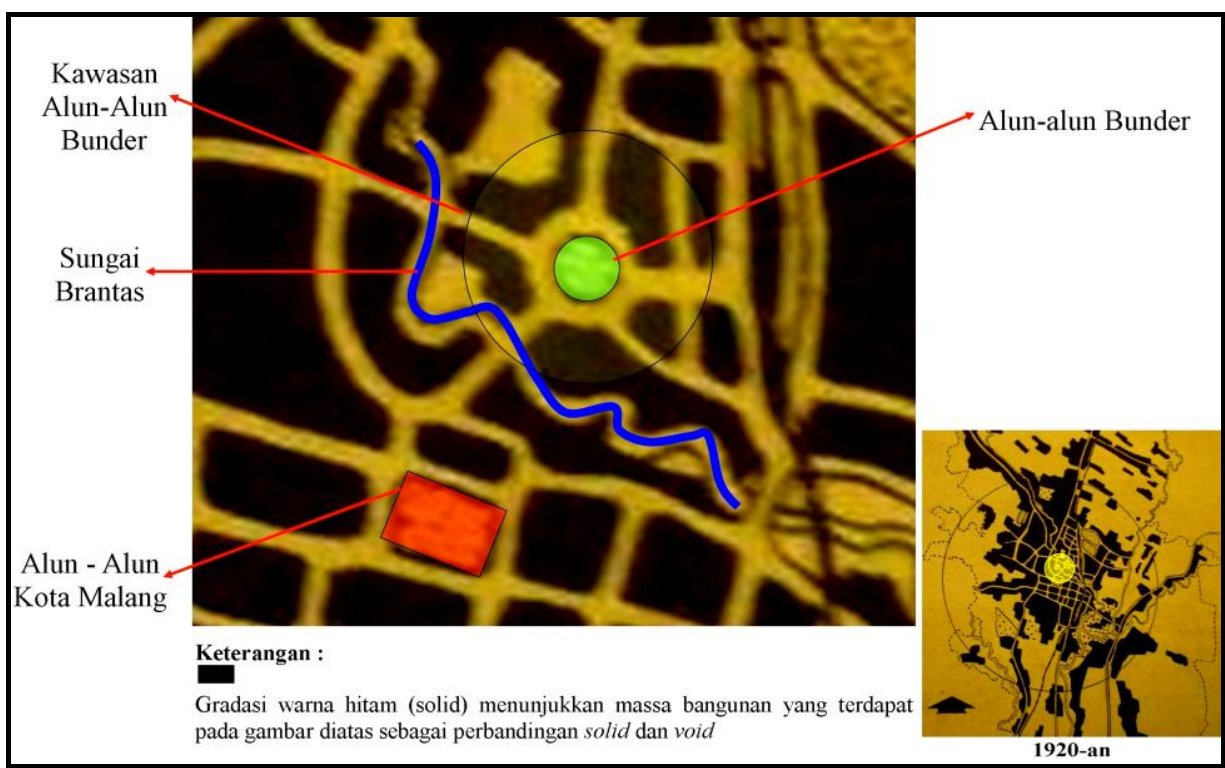

Gambar 12. Diachronic reading Alun-Alun Bunder tahun 1920

Sumber: Analisis yang diolah dari peta kuno Malang, galeri Museum Malang Tempo Doloe (2015)

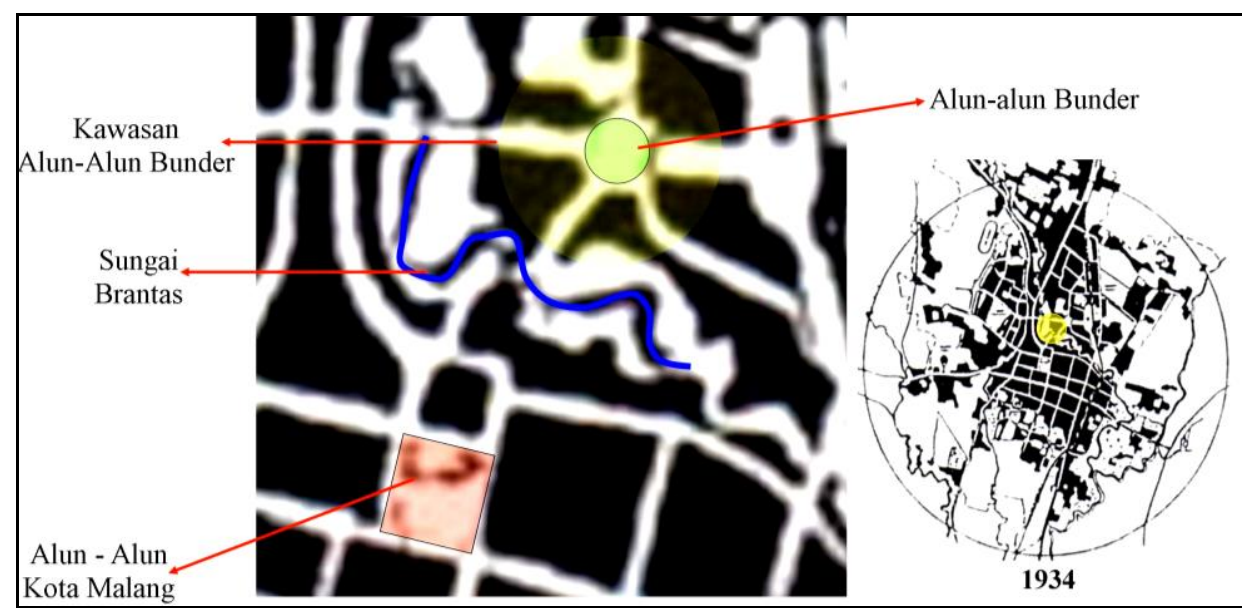

Gambar 13. Diachronic reading Alun-Alun Bunder tahun 1934

Sumber: Analisis yang diolah dari peta kuno Malang, galeri Museum Malang Tempo Doloe (2015) 
Pada tahun 1934 Kawasan Alun-Alun Bunder telah berkembang dan direncanakan dengan perancangan kota yang lebih baik oleh pemerintahan Belanda untuk menggantikan fungsi administrasi Alun-Alun lama (model Jawa) yang dinilai kuno dan tidak mencerminkan sebagai landmark kota Eropa, maka atas alasan tersebut dibentuklah kebijakan Bouwplan II dengan membangun pusat pemerintahan yang terletak pada Kawasan Alun-Alun Bunder, hal ini diikuti pula oleh berkembangnya kawasan di sekitarnya antara lain: pada Kawasan Splendid dibangun Hotel pada tahun 1920-an dan perumahan Belanda pada Jalan Tumapel pada tahun yang sama. (Gambar 14)

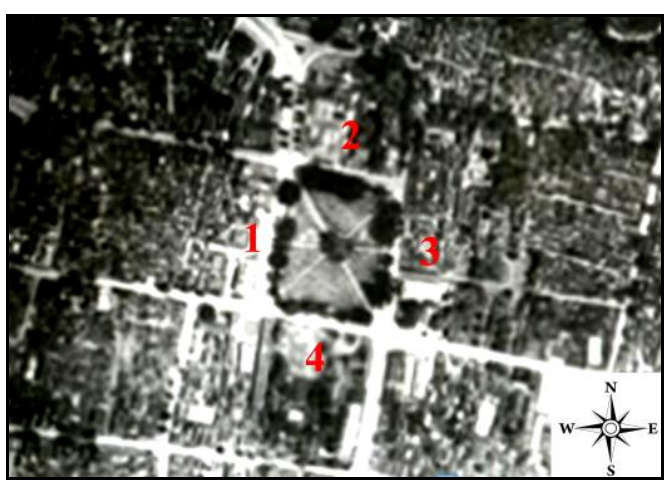

Gambar 14.Tipologi Alun-Alun Merdeka Sumber: Handinotodan Soehargo (1996).

Elemen yang termasuk di dalam bentuk Alun-Alun lama atau disebut dengan model perancangan gaya Jawa dan dilanjutkan oleh belanda adalah:

1. Masjid besar dan Kampug Arab;

2. Kantor Pemerintahan Belanda;

3. Penjara; dan

4. Rumah Bupati.

Bentuk tipologi desain Alun-Alun Merdeka sangat mencirikan dan mencirikan sebagai ruang terbuka yang banyak ditemukan di sebagian kota di Indonesia. Alun - Alun difungsikan sebagai tempat memberikan pengumuman dan memberikan hukuman bagi masyarakat yang melanggar hukum. Peletakkan Masjid, Kampung Arab dan Kantor Pemerintahan menunjukkan pola yang identik dengan sebagian besar AlunAlun di Indonesia yang pernah diperintah oleh kerajaan, dengan posisi Masjid terletak berdekatan dengan Alun-Alun. (Gambar 15 dan Gambar 16)

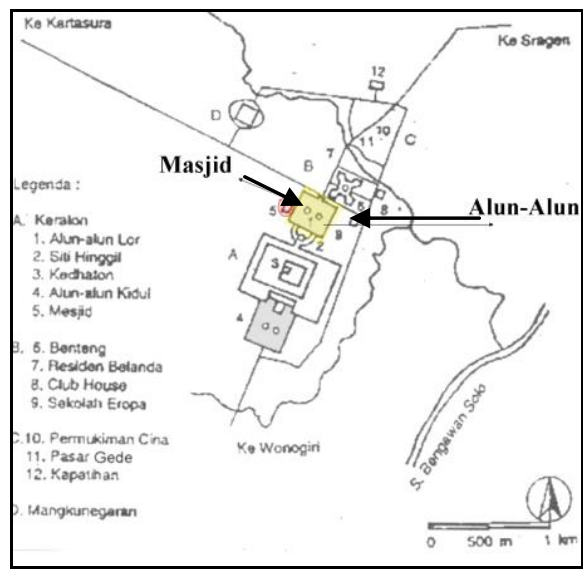

Gambar 15. Ilustrasi tipologi Alun-Alun Jawa di Surakarta tahun 1860

Sumber: Museum Radya Pustaka, Surakarta (2016)

Pada tahun 1938 Kawasan Alun-Alun Bunder tidak banyak berubah dari tahun 1934 karena pembacaan analisis diachronic reading dengan interval tahun yang pendek sehingga bangunan dan bentuk pola solid dan void dari Kawasan Splendid masih sama dengan tahun 1934. (Gambar 17) 


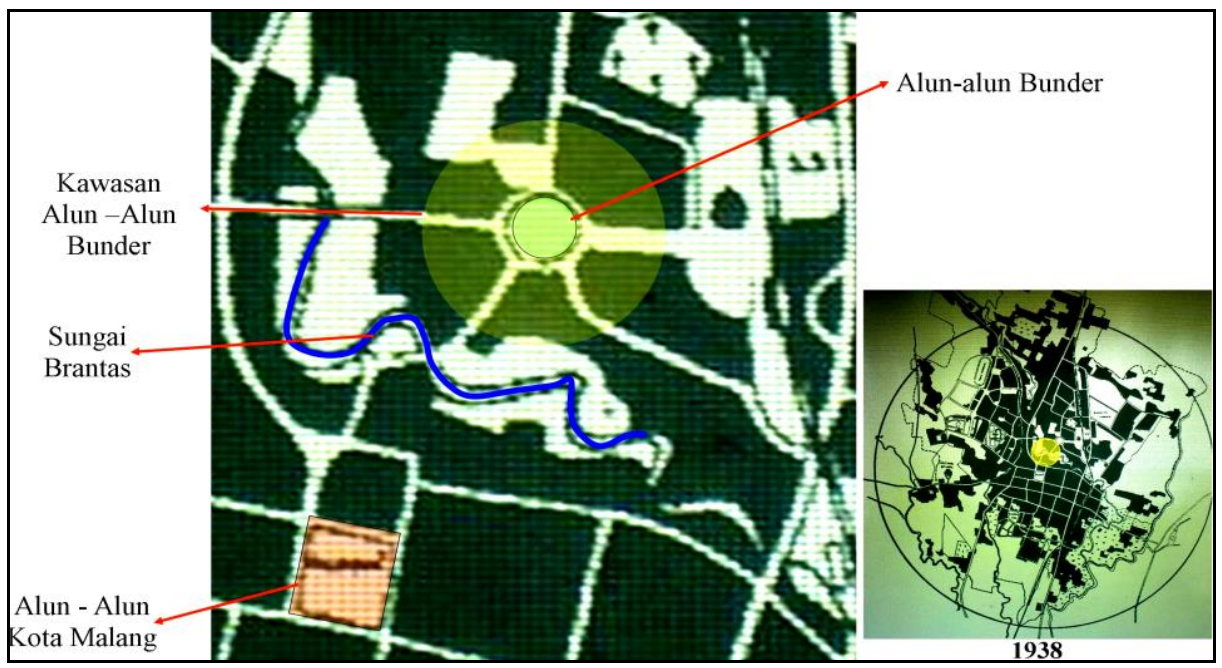

Gambar 16. Diachronic reading Alun-Alun Bunder tahun 1938

Sumber: Analisis yang diolah dari peta kuno Malang, galeri Museum Malang Tempo Doloe (2015)

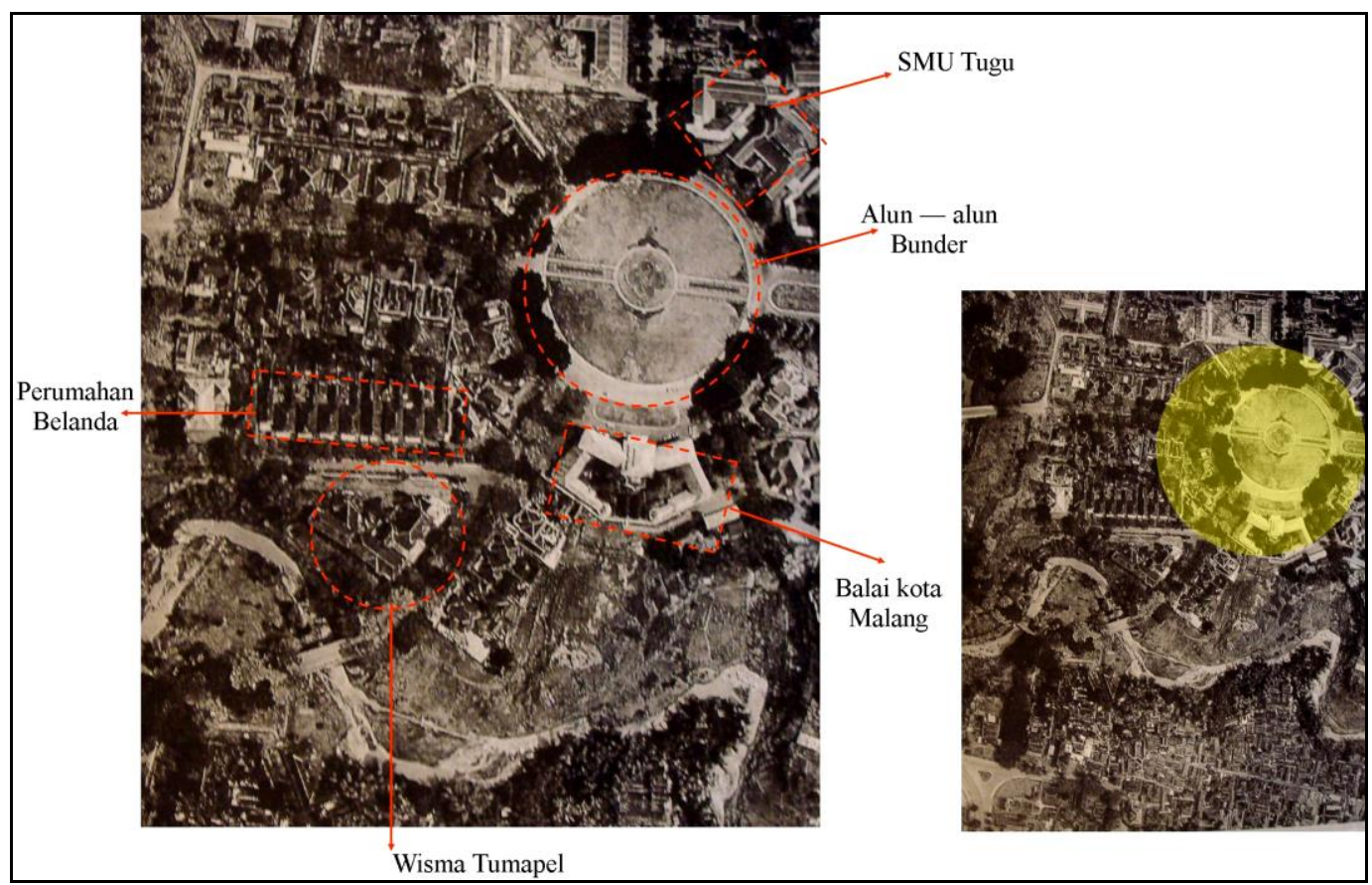

Gambar 17. Diachronic reading Alun-Alun Bunder tahun 1956

Sumber: Analisis yang diolah dari peta kuno Malang, galeri Museum Malang Tempo Doloe (2015)

Pada tahun 1956 terlihat jelas pola Kawasan Alun-Alun Bunder terutama pada Kawasan Splendid dengan pola fasade rumah dan model perumahan, merupakan bangunan rumah deret dengan tipikal fasade yang sama. (sebagai ciri khas Belanda). Hal ini dapat dilihat dari bentuk atap setiap rumah pada Jalan Tumapel antara bangunan satu dengan yang lain memiliki kemiripan. Pada tahun itu sudah ada Hotel Splendid Inn dan sudah berganti kepemilikan oleh Universitas Negeri Malang, Hotel ini menghilang setelah tahun 1935-an. Desain Alun-Alun Bunder pada tahun itu masih berupa tanah lapang, tugu dan kolam teratai, namun belum berpagar. Pasca deklarasi kemerdekaan setelah Kota Malang dihancurkan dan 
kemudian dibangun ulang setelah tahun 1945, Presiden Soekarno sebagai Presiden Republik Indonesia kesatu meresmikan monumen untuk memperingati kemerdekaan dari Belanda dengan disertasi pidato dan meresmikan monumen Tugu di depan Balai Kota Malang yang saat ini dikenal dengan istilah Alun-Alun Bunder. (Gambar 18, Gambar 19, dan Gambar 20)
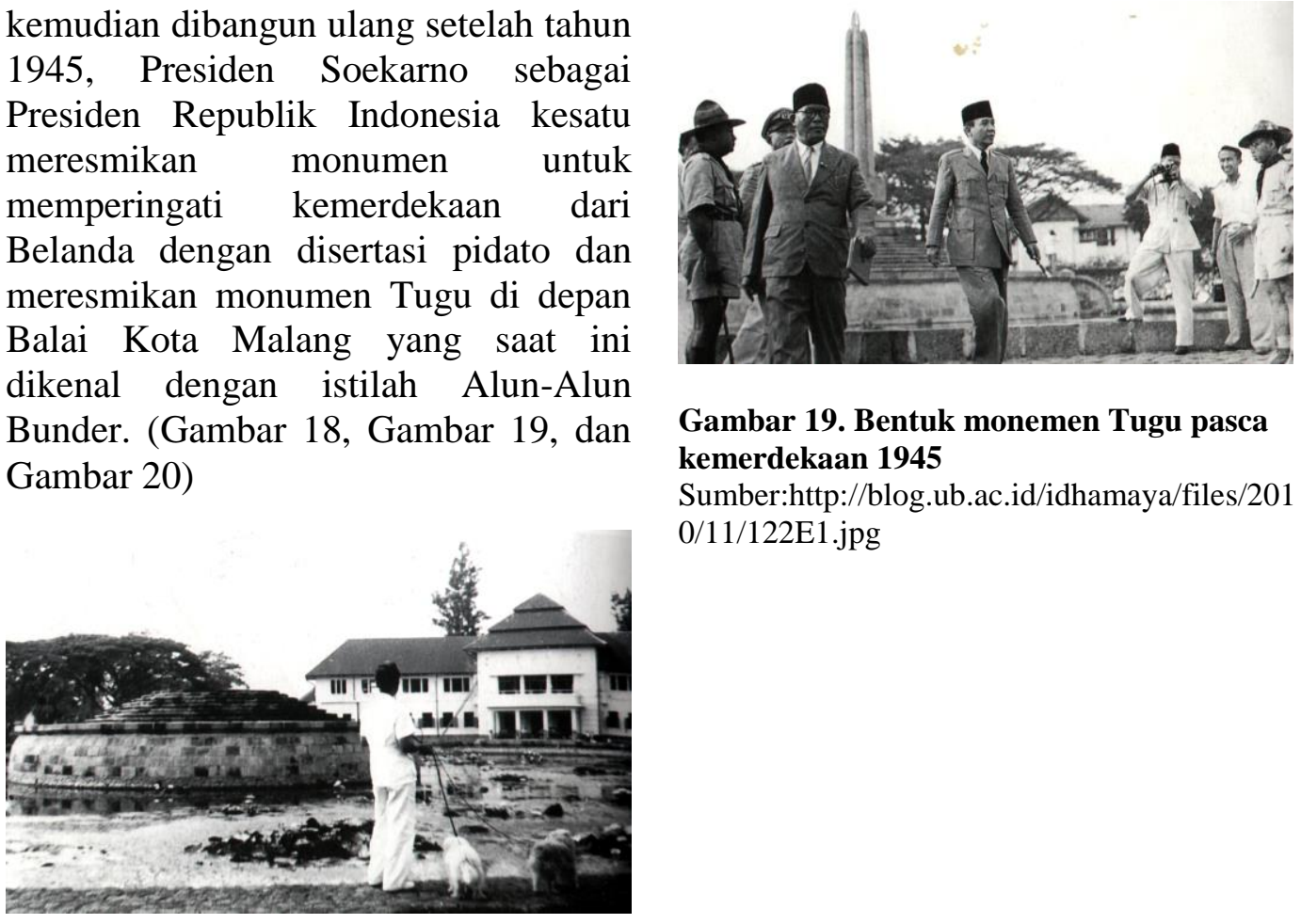

Gambar 19. Bentuk monemen Tugu pasca kemerdekaan 1945

Sumber:http://blog.ub.ac.id/idhamaya/files/201 0/11/122E1.jpg

Gambar 18. Bentuk monemen Tugu sebelum kemerdekaan 1945

Sumber:http://blog.ub.ac.id/idhamaya/files/201 0/11/122B1.jpg.

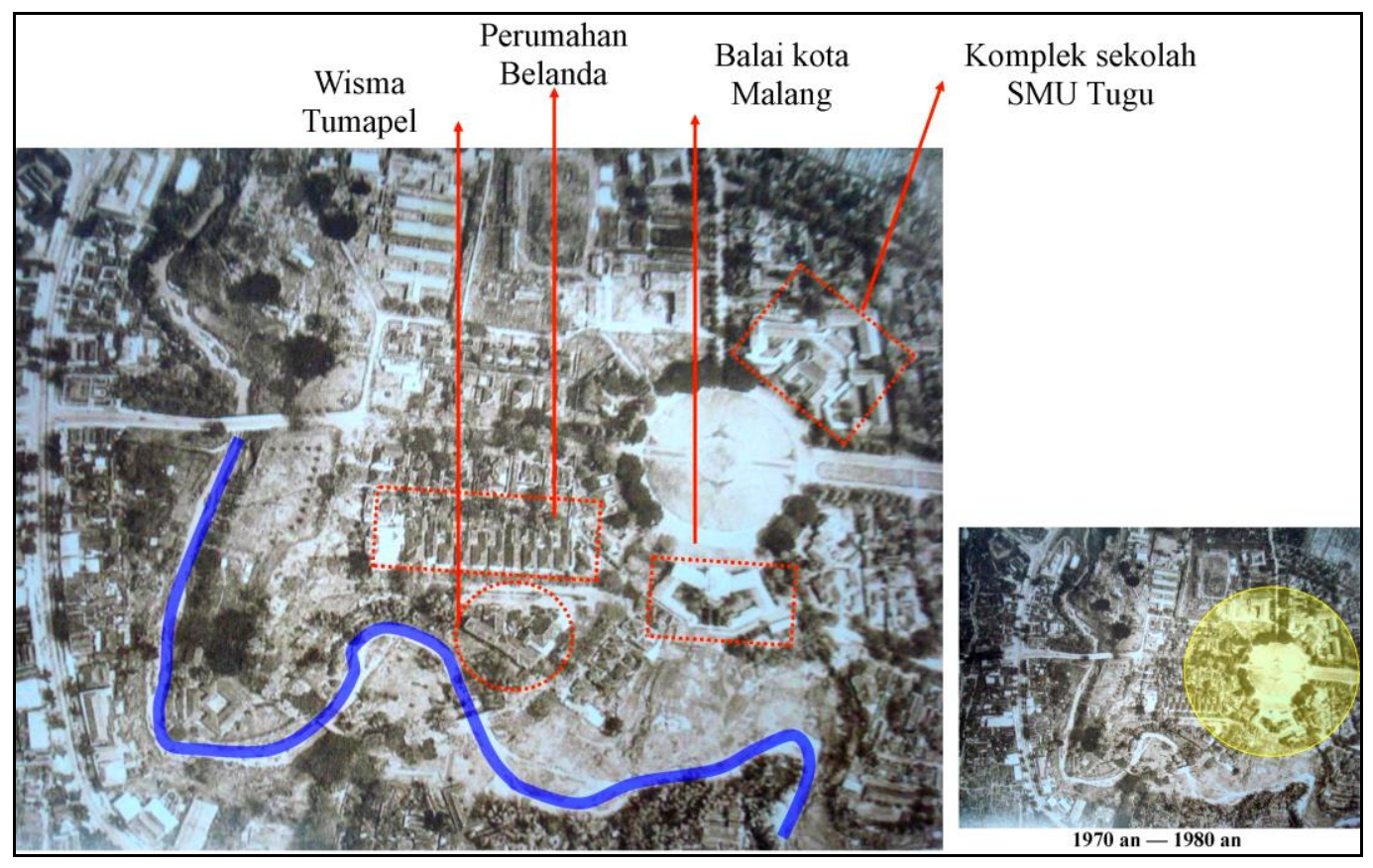

Gambar 20. Diachronic reading Alun-Alun Bunder tahun 1970-1980

Sumber: Analisis yang diolah dari peta kuno Malang, galeri Museum Malang Tempo Doloe (2015)

Pada interval tahun 1970 - 1980 lahan di sekitar Kawasan Alun-Alun pengunaan pola meruang dan tata guna Bunder berubah menjadi perumahan 
Belanda. Hotel Splendid Inn beralih fungsi menjadi Wisma IKIP, sedangkan Hotel Splendid Inn dipindahkan dan dibangun ulang pada area yang terletak di depan Wisma IKIP / Wisma Tumapel, dengan menempati bekas rumah warganegara Belanda yang dibeli oleh seorang
Indonesia (Museum Malang Tempo Doloe, 2015). Pengunaan lahan berupa pasar burung dan bunga pada interval tahun ini masih belum ada, hanya saja terdapat pasar senggol, yaitu istilah pasar yang hanya ada pada malam hari di Kota Malang, pasar ini terletak di Kawasan Splendid. (Gambar 21)

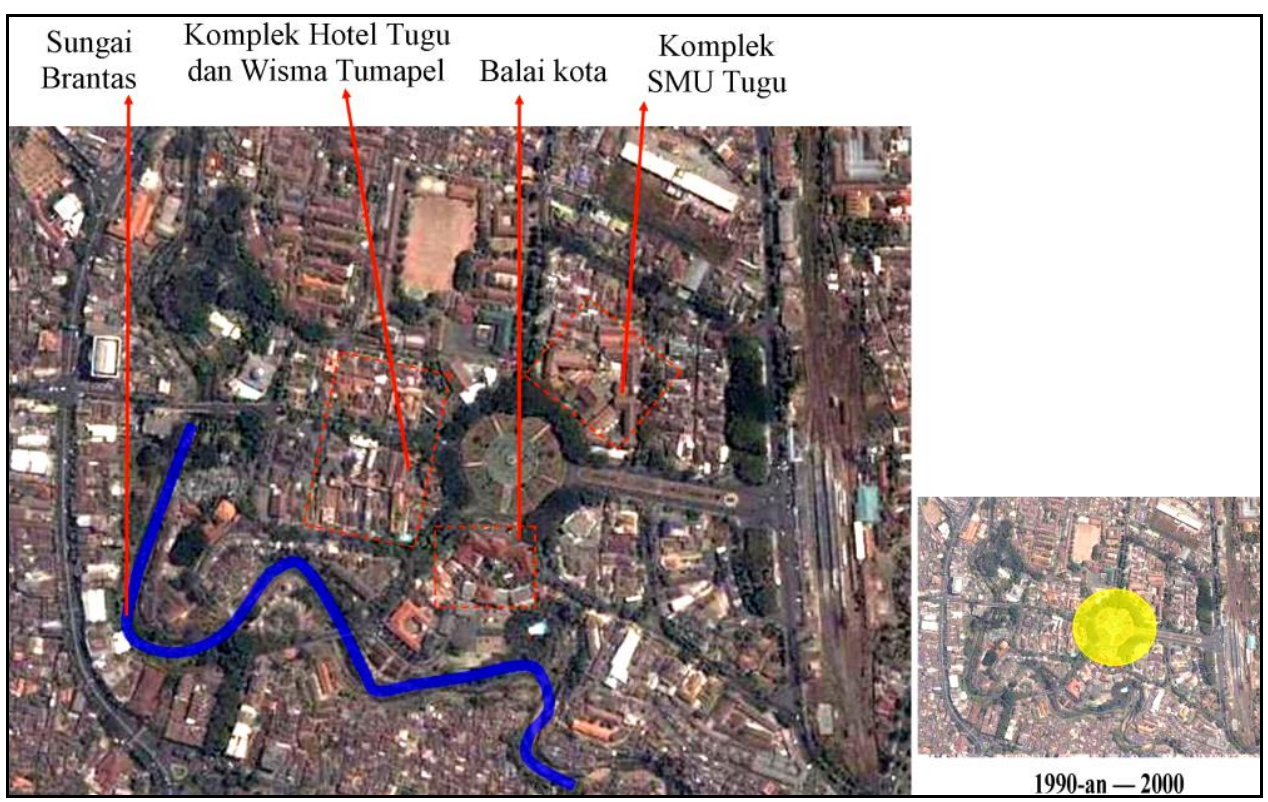

Gambar 21. Diachronic reading Alun-Alun Bunder tahun 1990-2000

Sumber: Analisis yang diolah dari peta kuno Malang, galeri Museum Malang Tempo Doloe (2015)

Tahun 1990-2000 Kawasan Alun-Alun Bunder mengalami perubahan guna lahan dan fungsi bangunan, perubahan ini, yaitu fungsi bangunan Wisma Tumapel dan perumahan Belanda yang sebelumnya tersusun rapi dengan model rumah deret. Perubahan bentuk ini berupa merenovasi bentuk elemen fasade dari sebagian bangunan namun tanpa merubah bentuk aslinya. Bangunan Wisma IKIP masih tetap sama bentuknya namun dengan fungsi guna bangunan yang berubah, yaitu bangunan yang awalnya berupa rumah menjadi gereja. Pada tahun 2000, pemerintahan Kota Malang mulai melakukan penambahan design, yaitu dengan cara mempagari ruang terbuka di Alun-Alun Bunder. (Gambar 22 dan Gambar 23)
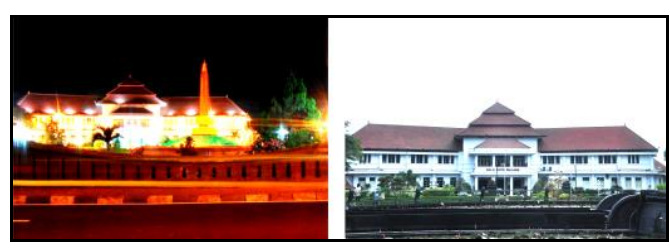

Gambar 22. Pagar beton diluar bunderan dan pagar besi di dalam monemen Tugu Sumber: Dokumentasi Putra (2016) 


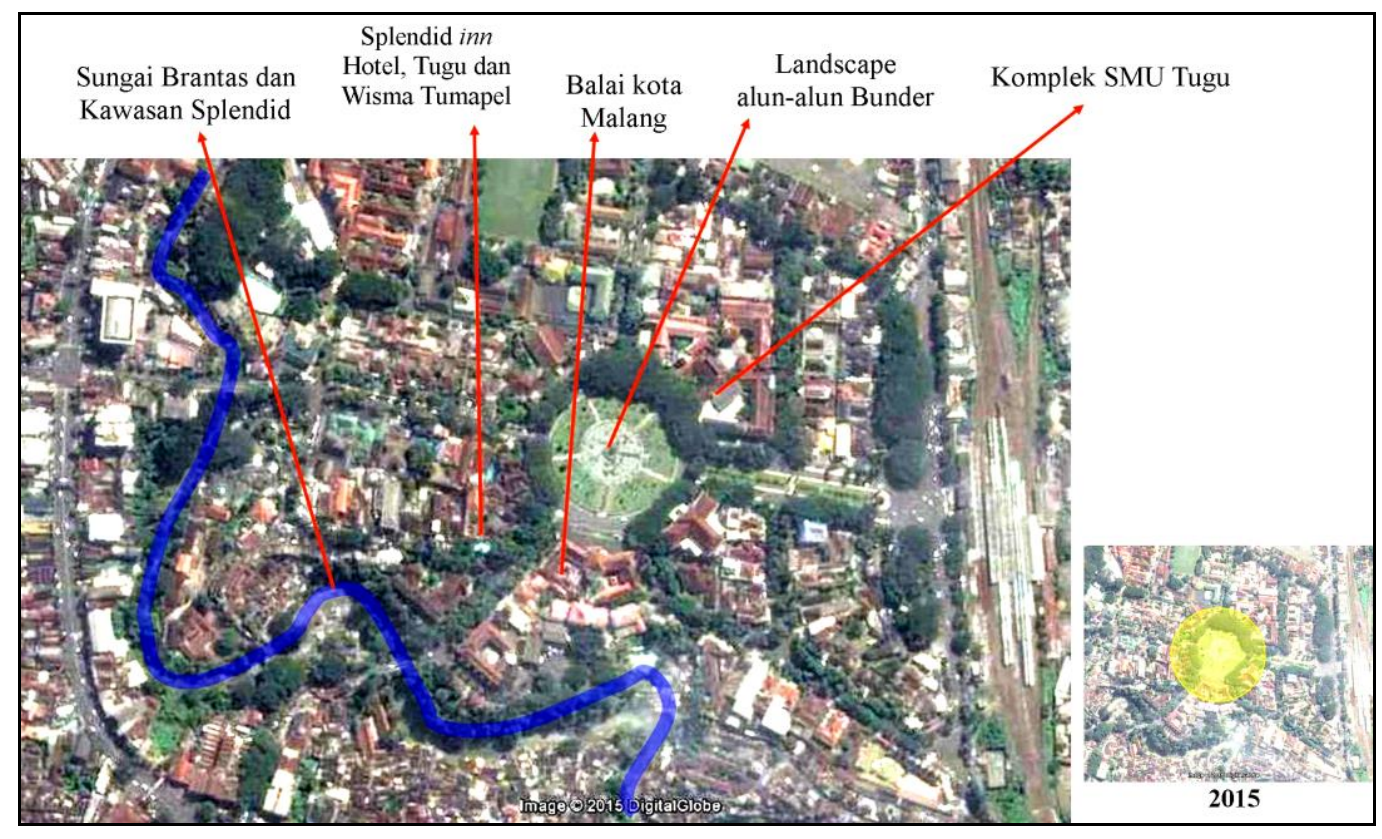

Gambar 23. Diachronic reading Alun-Alun Bunder tahun 2015

Sumber: Analisis yang diolah dari foto citra udara kota Malang, (2015)

Tahun 2015 Kawasan Alun-Alun Bunder berubah menjadi salah satu landmark di Kota Malang, landscape taman yang terletak di depan Balai Kota yang dikelilingi oleh bangunan kuno dan Sungai Brantas menjadi image Alun-Alun Bunder sebagai wajah Kota Malang.

Dari serangkaian pembacaan sejarah berdasarkan peta perkembangan Kota Malang, diperoleh sintesa analisis antara lain:

1. Pada tahun 1882 - 1934: Tidak ada bangunan sama sekali pada Kawasan Alun-Alun Bunder, hanya dilalui oleh eksisting bentang alam berupa Sungai Brantas sebagai salah satu pola pembentuk Kota Malang.

2. Pada tahun 1934 - 1956: Ternyata bangunan yang tumbuh di Kawasan Alun-Alun Bunder beserta open space dikembangkan mengikuti pola rencana kawasan Bouwplan II dari pemerintah Belanda yang diwakili oleh Ir.Karsten.

3. Pada tahun 1956 - 2000: pada masa ini merupakan masa transisi dari
Kawasan Alun-Alun Bunder, rumah Belanda banyak berubah fungsi menjadi sarana peribadatan dan rumah pribadi. Fungsi bangunan didepan public space/taman berubah fungsi, meskipun sebagian fasade bangunan masih dipertahankan, hanya terjadi renovasi atau penambahan dari elemen bangunan kuno.

4. Pada tahun 2000 -2015: terlihat jelas bahwa pola meruang Kawasan Alun-Alun Bunder sudah sangat berbeda dengan tahun 1950-an dan 1900-2000-an karena banyak bermunculan bangunan baru dan sebagian di antara bangunan tersebut mengalami sentuhan renovasi bangunan, untuk fasade bangunan yang masih asli antara lain: Balai Kota Malang, Gedung DPRD, SMU Tugu, Hotel Splendid Inn dan Wisma Tumapel.

Untuk membaca pola keterkaitan landscape Alun-Alun Bunder terhadap kawasan di sekitarnya digunakan teknik analisis syncronic reading, yaitu 
dengan memetakaan path, nodes sebagai elemen urban design pada Kawasan Alun-Alun Bunder. (Gambar 24)

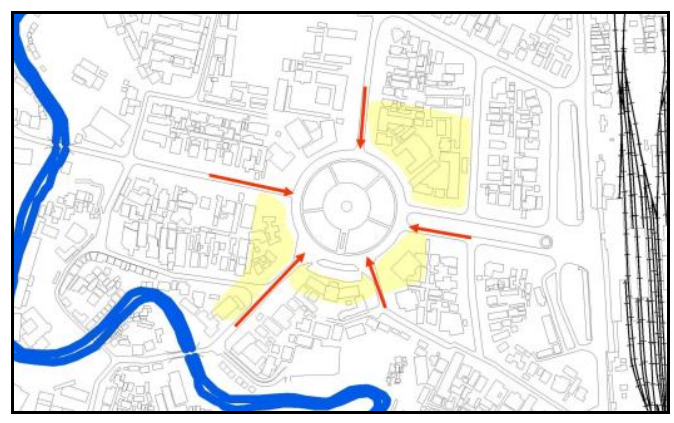

Gambar 24. Elemen path dan nodes

Sumber: Hasil Survei (2016)

Dari kondisi eksisting persebaran objek wisata/bangunan bersejarah di kawasan studi kemudian dikaitkan dengan elemen perancangan kota, yaitu path dan nodes Kawasan Alun-Alun Bunder yang dapat dilihat pada gambar di atas dengan garis panah merupakan path dan nodes yang terdapat pada kawasan merupakan simpul pertemuan dari setiap koridor jalan, sehingga diperoleh hasil model linkage kawasan (Gambar 25).

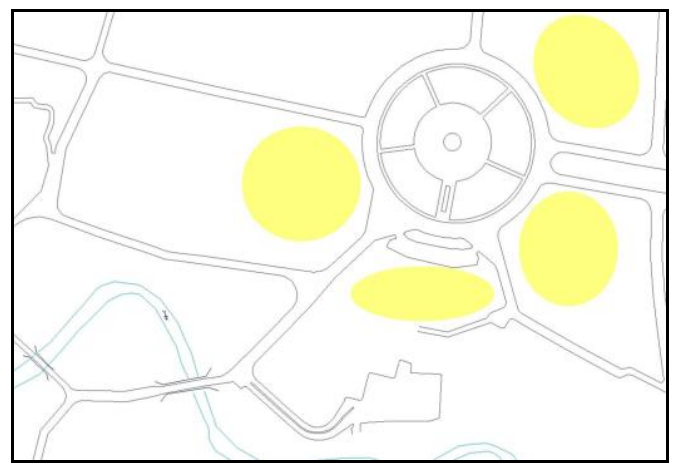

Gambar 25. Permodelan linkage.

Sumber: Hasil Analisis (2016)

Hasil penggabungan pola linkage yang terbentuk pada Kawasan Alun-Alun Bunder dapat disimpulkan bahwa kawasan ini terbentuk dari gabungan antara tiga pola linkage yang disatukan ke dalam satu kawasan, pola yang terbentuk antara lain:

linkage visual yang terbentuk dari garis dan koridor yang secara umum diwakili melalui deretan massa bangunan, koridor jalan, serta pedestrian way pada setiap objek yang terdapat di Kawasan Alun-Alun Bunder. (Gambar 26)

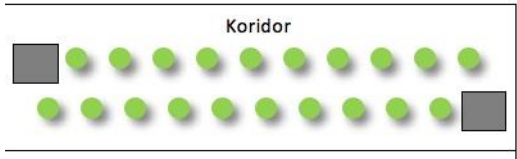

Gambar 26. Ilustrasi linkage visual Sumber: Zahnd (1999)

linkage struktural pada Kawasan AlunAlun Bunder terbentuk dari empat sub struktur yang saling dihubungkan dapat ditarik kesimpulan apabila pola dari linkage struktural yang terbentuk pada Kawasan Alun-Alun Bunder merupakan pola tembusan dan linkage secara kolektif membentuk pola groupform karena setiap objek terletak berdekatan dan membentuk kesatuan yang dihubungkan oleh jalan kolektor sebagai penghubungnya untuk diintegrasikan kemudian dipertemukan di satu titik, yaitu point of view landscape Alun-Alun Bunder. (Gambar 27)

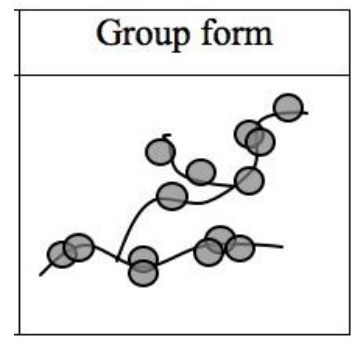

Gambar 27. Ilustrasi linkage kolektif Sumber: Zahnd (1999) 


\section{Kesimpulan}

Diketahui apabila beberapa objek pada Kawasan Alun - Alun Bunder hingga saat ini masih bertahan sesuai dengan bentuk awal dibangun atau rencana bouwplan. Objek tersebut antara lain: Wisma Tumapel, beberapa bekas permukiman Belanda di Jalan Tumapel dan Jembatan Brantas, Balai Kota Malang, Hotel Tugu, SMU Tugu dan Hotel Splendid Inn. Begitu pula dengan bentuk jalan yang tidak berubah dari pertama direncanakan hingga saat ini, yaitu pola jalan dengan orientasi menuju the circle. Strategi preservasi terhadap objek yang bernilai historis diperoleh dengan cara menguatkan potensi objek tersebut melalui tindakan mempertahankan fungsinya. Dengan memunculkan objek landscape Alun Alun Bunder tersebut sebagai landmark agar menjadi daya tarik wisata. AlunAlun Bunder merupakan karya dari Ir Karsten dan objek ini dibangun untuk menggantikan peranan Alun-Alun kota yang lama karena dinilai memiliki model Jawa yang pada saat itu dianggap kuno dan kurang mencermikan tipologi Kota Eropa.

\section{Daftar Pustaka}

Carr, S., et. al (1992). Public space. Cambridge: Cambridge University Press.

Darjosanjoto, E.T.S. (2006), Penelitian arsitektur di bidang perumahan dan permukiman. Surabaya: ITS Press.

Handinoto \& Soehargo, P. (1996). Perkembangan kota dan Arsitektur Kolonial Belanda di Malang. Yogyakarta: Penerbit Andi dan Lembaga Penelitian dan Pengabdian kepada Masyarakat Universitas Kristen Petra Surabaya.
Krier, R. (1979). Urban space. New York: Rizzolli International Publication.

Lynch, K. (1960). The image of the city. Massachusetts Institute of Technology.

Moughtin, C. (1992). Urban design: street and square. University of Nottingham, London.

Rencana Tata Ruang Wilayah Kota Malang, 2010-2030, Pemerintah Kota Malang.

Rossi, A. (1982). Architecture of The City. Cambridge: MIT Press.

Shirvani, H. (1985). The Urban Design Process. New York: Van Nostrand Reinhold Company.

Spreiregen, P. (1986). Urban design: The architecture of town and cities. New York: McGraw-Hill Book Company.

Trancik, R. (1986). Finding lost space. Theories of urban design. New York: Van Nostrand Reinhold Company. 